\title{
The Right to a Privilege? Homonormativity and the Recognition of Same-sex Couples in
} Europe

\section{Introduction}

The regulation of so-called gay marriage is at the centre of a heated political debate across Europe. Often heralded as the most advanced frontier of human rights protection, the discussion, and inscription in national legislation of the right to marry for same-sex couples has ambiguous social, economic and political contours. The 2013 debates in the Parliaments of France and the United Kingdom substantiate the fact that something more than the achievement of full equality is at stake with regard to the issue of the marriage rights of same-sex couples. Far from merely discarding the heteronormative interpretation of marriage, as Johnson (2012: 147) seems to suggest, broadening the concept of 'family' to include same-sex couples constitutes a substantial preservation of the social, political and economic status quo. By means of a co-opting a segment of non-heterosexual individuals, in terms of what Duggan (2003) has defined as 'homonormativity', entering marriage presupposes a substantial adherence to the conservative character of extant institutions, rather than a challenge to them by means of political action.

This article aims to analyse critically the way in which the European judicial and non-judicial practice of human rights frames marriage for same-sex couples as the crowning achievement of full equality, whilst simultaneously concealing the extent to which the call for marriage equality responds to a need to obtain a 'privilege' in social, political and economic terms. This objective is pursued by combining a socio-legal analysis of selected cases of the jurisprudence of the European Court of Human Rights ('the Court') regarding same-sex couples in relation to marriage, adoption and socio-economic rights, with an ethnographic account of the work of the Commissioner for Human Rights of the Council of Europe ('the Commissioner') on these same issues. 
The cases chosen for this analysis reflect the necessity of abandoning a purely chronological description of the evolution of the jurisprudence. Attention, instead, has been paid to cases that are relevant to homonormative narratives and to the socio-economic implications of marriage equality, which are not sufficiently acknowledged, in the current socio-legal literature on same-sex couples in Europe. At the same time, the decision to include data from the fieldwork and first-person observations conducted at the office of the Commissioner serves the purpose of furnishing a somehow new perspective on the way in which discourses on same-sex couples are framed, within the Council of Europe (CoE) itself, beyond the narrow judicial framework of the Court.

The intention of this research is that to constructively de-romanticise, to some extent, the concept of 'marriage equality', in order to emphasise the extent to which the CoE participates in the definition of a narrow (neo)liberal conception of equality for lesbian, gay and bisexual (LGB) persons, substantially incarnated by the ultimate goal of gaining the right to get married. The first part of this article discusses the recognition of same-sex couples as 'families' in terms of their respectability and full inclusion into the social fabric of member states of the CoE. This analysis allows a consideration of marriage as being framed more in terms of 'privilege' rather than as a formal human right. The second part moves to the analysis of different strands of the jurisprudence of the Court, showing the economic implications that marriage equality entails for member states in terms of the concession of a 'privilege' to same-sex couples. The third part considers the issue of adoption and custody for same-sex couples from the perspective of homonormativity, linking it to the notion of the 'good parent' both in the courtroom and outside it.

\section{We are family (?): an incomplete recognition of same-sex relationships}

The lack of recognition of same-sex couples as families is often seen as an exclusion from the sphere of civil legitimacy and as a way of foreclosing the possibility of political action in the Arendtian sense. As Butler (2002: 17) has maintained in drawing the difference between marriage 
and kinship: 'to be legitimised by the state means to enter into the terms of the legitimation offered there and to find out that one's public and recognisable sense of personhood is dependent on the lexicon of that legitimation'. Hence, the denial of recognition goes hand in hand with the denial of respectability.

Marriage, however, has not always been the main preoccupation of the LGB movement. Scholars such as Kandaswamy (2008) and Polikoff (2005) have suggested that the LGB movement has considerably shifted its priorities in relatively recent times, in favour of a narrower - and more liberal-conservative - social and political agenda. Polikoff (2005: 918) has observed that the LGB activists have: 'abandon[ed] a longstanding commitment to defining and evaluating families based on function rather than form, distancing themselves from single-parents and divorced families, extended families, and other stigmatised child-rearing units'. This shift can be said to wink, contemporaneously, to both Duggan's homonormativity and to heteronormativity. Indeed, as Brandzel (2005) has affirmed, heteronormativity is built around a certain image of the heterosexual couple as: 'white, middle-class, child rearing and materialistic' (2005: 196). In the context of the law, therefore, heteronormativity and homonormativity can be said to coexist and operate as a doublebinding system of regimentation of individuals, in a condition of distant synchronicity, with the aim of achieving, by different means, normalisation and uniformity.

The legal and socio-legal scholarship on the recognition of same-sex relationships has predominantly approached the issue according to a linear temporality, marked by either 'evolutions' or 'setbacks' at both the national and international level (Waaldijk 1994, 2000, 2003; Wintemute 1997, 2001; Johnson 2012). The idea that linear progress can be achieved in the domain of the law on this particular issue is well illustrated by the strategic intensification of applications to the Court, during the last five years, concerning the interpretation of Article 12 of the European Convention on Human Rights (ECHR) on the right to marry and found a family, by both lesbian and gay couples. On the one hand, applicants have tried to encourage the Court to adopt a more inclusive interpretation of the wording of Article 12 ECHR. On the other hand, they have also sought to 
transfer their request to become respectable from the national to the international juridical and political forum, making recourse, therefore, to a symbolic investment in their intelligibility as bearers of human rights.

Perceived by applicants both as a last resort and a sounding board for their requests, the Court has acted as the gatekeeper of the concept of family in the European continent, without major departures from the heteronormative description of marriage. Applicants had sought in the 1980s and the 1990s to challenge the formulation of the provision enshrined in Article 12 ECHR and to connect it with the 'family life' limb of Article 8 ECHR, without success. Only recently, ${ }^{1}$ has the specific strand of jurisprudence on the right to marry and found a family under Article 12 ECHR for individuals of the same gender acquired a systematic character and the advent of concerted litigation has activated a process aimed at shifting the balance in favour of a more inclusive interpretation of Article 8 ECHR and, possibly, of Article 12 ECHR.

In the 2010 landmark case of Schalk and Kopf v. Austria, the Court partially opened the way to new epistemological criteria to employ in the interpretation of the concept of 'family'. The two plaintiffs, two men who had been refused the right to marry by the Austrian authorities, had alleged a violation of Article 8,12 and Article 1 of Protocol 1 ECHR. The judgment is interesting in many respects. In the first instance the Court answered in the negative to the applicants' request to read the wording of Article 12 ECHR 'men and women of marriageable age' in the light of present day conditions. The particular linguistic expedient of considering men and women as two separate categories had been used by applicants to try to drive a wedge between the traditional concept of marriage and the Court's interpretation of it. Such an expedient, destined to fail in this case, had nonetheless determined an ambiguous positioning of the Court in relation to the controversial definition of the concept of 'family life' under Article 8 ECHR.

Prior to Schalk and Kopf v. Austria, the Court had never made any concession to the possibility that two persons of the same gender living together could be considered as a family. However, the terms on which that concession was made in this judgment were ambiguous. The result was a 
simultaneous flirting, on the part of the Court, with both heteronormative and homonormative narratives. While the Court conceded that same-sex couples could enjoy 'family life', this can only happen provided that some conditions are fulfilled. Furthermore, the non-governmental organisations (NGOs) intervening as third parties had sought to convince the Court that individuals in same-sex relationships were capable of forming 'long-term emotional and sexual relationships' (Schalk and Kopf v. Austria, 2010: para. 84). This rhetoric of commitment points directly to monogamous couples, on whom the burden of proof to demonstrate the solidity of their relationship lies. Moreover, it also works to exclude couples whose relationship does not comply with the set standards of the romanticised vision of love. To this extent, the intervening NGOs, in concert with the applicants, directly contributed to the enhancement of the homonormative narrative before the Court.

The Court, however, did not renounce its heteronormative framework of analysis of marital relationships and refused to state that the right to marry and found a family applies equally to all men and women, regardless of their sexual orientation. This ambivalence implies a qualitative assessment of the 'family life' of same-sex couples according to criteria that are inherently shaped by heteronormative standards. This, moreover, establishes the homonormative aspirations of applicants as being systematically sub-optimal with respect to heterosexual marriage. To this extent, the paradox in Schalk and Kopf v. Austria is that the judgment sanctions the existence of a limbo inhabited by those who, in theory, can qualify as a 'family', but who are, nonetheless, separate from heterosexual families.

Schalk and Kopf v. Austria also introduced issues relating to the exclusion from the benefits and entitlements that the exclusion from marriage for same-sex couples entails. The applicants, in fact, alleged a violation of Article 1 of Protocol 1 ECHR on the 'peaceful enjoyment of possessions', as well as a violation of Article 8 in conjunction with Article 14 ECHR. In this case, the Court had to evaluate whether it was possible for the state to treat individuals in similar situations, namely samesex and different-sex couples, in a different way. In its decision it made it clear that a wide margin 
of appreciation is granted to member states when 'it comes to general measures of economic and social strategy' (Schalk and Kopf v. Austria, 2010: para. 21). Member states are, therefore, granted discretion in deciding how to distribute benefits and entitlements, if this complies with precise socio-economic criteria and objectives. Later in the judgment, the Court also identifies a crucial distinction between the various legal consequences of recognised same-sex partnerships: material, ${ }^{2}$ parental $^{3}$ and other consequences $^{4}$ (Schalk and Kopf v. Austria, 2010: paras 32-34). The analysis of these consequences will form the central object of inquiry of the rest of this article.

However, before moving to the consideration of the various material consequences of the recognition of same-sex partnerships, it is important to acknowledge the role that other actors within the CoE play in shaping the European human rights agenda in relation to these issues. The Commissioner is one of these actors. As an independent body ${ }^{5}$ with awareness-raising and monitoring functions, he can make use of his diplomatic abilities and skills to act as a bridge between the interests of member states and the criticisms of non-governmental human rights actors. An ethnographic account of the fieldwork carried out in 2010 at the office of Commissioner Thomas Hammarberg offers a unique opportunity to balance a purely legal approach and further illustrates the strong homonormative connotations that the current debate on the recognition of same-sex relationships in Europe has. The Commissioner was, at the time, drafting a comprehensive pan-European socio-legal report on discrimination on grounds of sexual orientation and gender identity in the 47 member states. The report issued in 2011 treated systematically issues concerning both the recognition of same-sex relationships and issues related to parenting rights of LGB individuals.

As has been shown in relation to the jurisprudence of the Court, little margin for manoeuvre is left to international human rights institutions to reconfigure the meaning of concepts such as family or marriage. Even the Recommendations issued by both the Committee of Ministers (CM) (Recommendation $\mathrm{CM} / \operatorname{Rec}(2010) 5)$ and the Parliamentary Assembly (PACE) (Resolution 1728(2010)) - the two main political bodies of the CoE - only go as far as suggesting that states are 
free to extend marriage to same-sex couples but that there is no binding power, on the part of nondomestic actors, to impose such re-interpretation.

In his 2011 report, the Commissioner, by virtue of his independence, could adopt a more malleable stance than the Court, the CM and the PACE in relation to the interpretation of concepts such as family and marriage. The interest of the Commissioner in the family life of LGB persons was very strong. At the time when these ethnographic observations were carried out, the Commissioner and his staff were closely following the work of the Court. Precisely during the editing process of the above-mentioned report, the Court had just issued Schalk and Kopf v. Austria (2010) which was promptly included in the section of the report dedicated to partnership and family life.

Both in the report and in his activities the Commissioner adopted a cautious, and therefore not explicit, endorsement of marriage equality. It was perceptible, but not visible. Such caution was coupled with a significant degree of diplomatic ability in effectively raising awareness with national authorities on these issues, something which became apparent once the report was launched in June 2011 in Strasbourg. This official event was a gathering of different personalities, from delegates of national governments, national judicial institutions, NGOs activists, as well as representatives of the Organisation for the Security and Cooperation in Europe (OSCE), the United Nations Commissioner for Human Rights and the Fundamental Rights Agency (FRA) of the European Union.

As soon as the presentation of the report began, it became very apparent that the focus of the launch was to be on issues of discrimination (in employment, in the exercise of freedom of expression and freedom of assembly and association), hate speech and hate crime against LGBT persons, rather than marriage equality, let alone parenting rights. It was almost as if all the participants in the room were aware of the fact that that the consensus on issues touching on kinship and family life was fragile. A low profile on such topics was, indeed, chosen for the event. As a part of a strategicdiplomatic effort to bring to the table of discussion different actors from civil society, institutions and governmental and non-governmental actors, the Commissioner was trying to identify a 
'common denominator' that could serve as a first shared point of departure in order to approach these issues - controversial for some member states - in the first place. The issue of 'family life' certainly proved the least likely human rights issue on which such a broad convergence could be sought and achieved.

The Commissioner's awareness of the need to raise the issue of marriage equality 'strategically', however, has not diminished the extent to which his efforts have pushed in the direction of the depiction of the healthy, happy, monogamous homosexual couple. With all the best intentions, in fact, the strategy adopted by the office has been finely attuned to homonormative call to full inclusion of same-sex couples. Marriage is simply taken as a given; its value and material consequences are not substantially put into question. Therefore, although the Commissioner is a truly independent figure inside the $\mathrm{CoE}$, his discourse remains nonetheless embedded in the dynamics of respectability and 'normality' of same-sex couples with respect to their heterosexual equivalents. Hence, his efforts in the direction of persuading member states to broaden their conception of 'marriage' in national legislation take the form entirely of the concession of a privilege to a formerly excluded portion of the population, rather than a radical re-configuration of kinship structures.

On their side, member states can decide to what extent they want to give material form to homonormative calls for the recognition of same-sex partnerships. Each member state, in fact, could attach a particular value and a particular set of entitlements and privileges to the institution of marriage, as well as a different ideological and political value. To this extent, the call for a 'normalisation' of same-sex couples on the part of international human rights actors, such as the Court or the Commissioner, may sometimes collide with the national human rights agenda or with national interests. This particular aspect will become more apparent in the second section of this article, in which practical material consequences of the recognition of same-sex partnerships are discussed through the jurisprudence of the Court and the work of the Commissioner. 


\section{My privileges, your privileges: towards full equality?}

General considerations on the economic gains of marriage are well integrated into a broader neoliberal framework, beyond the mere principle of formal equality. Authors such as Badgett (2008) and Black, Sanders and Taylor (2007), building on Becker's (1973) analysis of the economics of family, have explored the economic principles underpinning the choice of getting married for samesex couples, identifying a series of material gains that can be obtained through marriage. Other authors, however, have gone further, in suggesting the existence of a link between the issue of marriage equality for same-sex couples and neoliberal political and economic policies. In particular, authors such as Kandaswamy (2008), Fineman (2009), McCluskey (2009) and Eng (2010) have argued that the model of equality sought by the proponents of same-sex marriage, is a concept of equality profoundly attuned with the neoliberal concept of 'autonomy'. McCluskey (2009: 131) illustrates this crucial aspect particularly well: 'free market economics rejects a political vision of justice, (...), it turns contested normative questions of public power into objective rational calculations of private individual sensibilities'. In the context of the current financial crisis, moreover, it is not uncommon to hear discourses about the family as the most important 'social safety net'

Hence, marriage equality, usually framed as a human rights issue, acquires the contours of an economic problem: how can a same-sex couple pay less tax? How can they receive more welfare benefits from the state? How can they inherit from a partner without significant losses in their patrimony? Warner (1999) and Robson (2009), in this regard, go as far as to suggest that the 'choice' to get married available to same-sex couples, may be dictated by a promise of a series of gains otherwise inaccessible to them without the acquisition of a particular marital status. In this respect, the very concept of 'families of choice', coined by Weston (1998), becomes invested with issues of agency and symbolic and material power. As Taylor (2009: 5) has observed, it is necessary also to ask who can afford to make the choice to have a family. Spade (2011: 62), furthermore, highlights 
the extent to which the issue of same-sex marriage also risks overshadowing other structural factors of inequality:

The framing of marriage as the most essential legal need of queer people, and as the method through which queer people can obtain key benefits in many realms, ignores how race, class, ability, indigeneity and immigration status determine access to those benefits and reduces the gay rights agenda to a project of restoring race, class, ability and immigration status privilege to the most privileged gays and lesbians.

Therefore, while Johnson (2012: 162) argues that marriage is a 'vital social institution', Franke (2006: 248) maintains, instead, that often the marriage debate is a 'distraction' that diverts the attention from the existence of broader and more complex underlying political issues, such as entanglements of policies touching on race, class and choices in domestic and foreign policy (Puar 2007). Some conditions of inequality, in fact, are hardly solved by the means of a marriage licence. As Brandzel (2005: 188) highlights, the advantages of same-sex marriage are tangible for middle and upper classes who already enjoy some forms of economic security, but are less tangible for poor or socially marginalised same-sex couples. Therefore, the mere focus on the importance of marriage for same-sex couples may overshadow inequalities based on race, class, ability, education that have an undeniable impact on life chances and personal development.

To this extent, the jurisprudence of the Court on the opportunity for same-sex couples to access marriage illustrates well the interrelationship between material and symbolic aspects of marriage. The three cases chosen, C. and L. M. v. the United Kingdom (1989), Mata Estevez v. Spain (2001) and Karner v. Austria (2003), present elements that point directly to the economic significance of marriage and to the benefits associated with it. The decision to analyse them jointly derives from the intention to offer an overview, as complete as possible, of the different economic issues that are entangled with the request to have one's relationship recognised before the law. 
C. and L. M. v. the United Kingdom offers interesting insights into the way in which the material enjoyment of human rights may differ radically from the formal assertion of universal principles. The case concerned an Australian national (the first applicant), who had given birth to a daughter (the second applicant) via artificial insemination ${ }^{7}$ and had been living in a stable relationship with a British national in the United Kingdom. Since the first applicant's employer had not confirmed her permanent employment in the country, both applicants (mother and daughter) were to be deported to Australia. After having exhausted all internal remedies, the applicants had lodged a complaint, alleging the violation of articles 8, 12 and 8 in conjunction with 14 ECHR. In its decision, the Commission had declared the application inadmissible.

While the Court had found that the relationship between the two women qualified as 'private life' under Article 8 , it had not recognised that it could also qualify as 'family life'. ${ }^{8}$ Hence, for the purposes of British immigration law, it was not relevant whether the applicants were enjoying private life in the United Kingdom if it could not also be considered as family life:

the Commission finds that a lesbian partnership involves private life, within the meaning of Art. 8 (...) of the Convention. However, although lawful deportation will have repercussions on such relationships, it cannot, in principle, be regarded as an interference with this Convention provision, given the State's right to impose immigration controls and limits (C. and L. M. v. the United Kingdom, 1989).

This excerpt from the Commission's decision highlights the prominent position of national interests and national security, broadly speaking. It is also striking because the Commission recalls the fact that, in previous cases, the Court had found instances in which Article 8 ECHR had been violated in relation to the deportation of individuals from countries where their close family resided. Strangely enough, however, two women and a child living under the same roof were considered only capable of having a private - therefore hidden from the public - life. 
Furthermore, the Commission also maintained that immigration law had the priority of protecting the traditional family, as if the trade-off was between protecting the state and allowing individuals to take advantage of their immigration status. It was precisely this sort of preoccupation, the possibility of fraud, that also pushed the applicants, to persuade the Commission that they did not intend to take advantage of public funds, public housing or other benefits. The applicants were, at the same time, both trying to demonstrate the genuineness of their family project and were seeking a status of respectability with regard to possible allegations of fraudulent conduct in the enjoyment of social and economic benefits.

The narrative of the 'respectable couple' played an important role in the construction of the applicant's complaint. The plaintiffs had, in fact, tried to advance the argument that it would have been in the best interests of the child ${ }^{9}$ to grow in a "stable monogamous relationship of two persons", playing on the homonormative paradigm of familial normality. In declaring the application inadmissible, however, the Commission implicitly maintained that the deportation of the applicant helped, to some extent, to protect both the traditional (heterosexual) family and national interests. Nothing is known about whether the applicants and C's partner were able to maintain or restore their family life after the deportation to Australia. Yet, this situation is all too common when bi-national couples face separation because of immigration policies. The possibility of accessing means and instruments, either material or symbolic, with to resort to the Court in Strasbourg are crucial in these instances. Couples in similar situations, whether heterosexual or homosexual, may not necessarily possess the cultural capital and economic means to seek justice and, even when they do, their claims are screened with extreme severity, as demonstrated by the Court's jurisprudence on scam marriages. ${ }^{10}$

C. and L.M. v. the United Kingdom shows the short circuit of the Commission and the Court in making a surgical distinction between private life and family life, partly motivated by the attempt to protect (heterosexual) marriage as a privilege. From a trans-historical perspective, Mata Estevez v. Spain and Karner v. Austria further illustrate this issue. The two cases concern respectively the 
request for social security allowances for a surviving spouse (Mata Estevez v. Spain, 2001) and the succession to a tenancy agreement after the death of the applicant's partner (Karner v. Austria, 2003). The joint analysis of these cases shows how a specific interpretation of 'family life' functions as an inescapable regulating factor for the public distribution of financial or economic resources. It could be argued, therefore, that the rationale for denying the right to marry to some individuals, could be motivated by the intention to maintain a system of privileges, rather than by eminent ideological, moral or religious motives.

The Court (and the Commission in the case of Mata Estevez v. Spain) has implicitly recognised during these years, by making extensive use of the margin of appreciation principle, the right of member states to regulate issues that have a broad economic and social significance. In Mata Estevez v. Spain ${ }^{11}$ the Commission confirmed its previous jurisprudence, ${ }^{12}$ excluding the possibility that a homosexual relationship could fall within the notion of 'family life' under Article 8 ECHR. Same-sex couples, therefore, had no legal means to sanction their partnership. In declaring the applicant's claim for a violation of Article 8 in conjunction with Article 14 ECHR inadmissible, the Commission had found that the difference in treatment between non-married heterosexual couples and same-sex couples was not discriminatory, since the decision to limit the enjoyment of survivors' pensions to married couples was aimed at pursuing a legitimate objective, namely 'the protection of the family based on marriage bonds' (Mata Estevez v. Spain, 2001: p. 5).

The 'protection of the traditional family' also plays a central role in Karner v. Austria, from the perspective of the proportionality employed by the Austrian state in the protection of the family. The first difference between Mata Estevez v. Spain and Karner v. Austria is the magnitude of the economic interests at stake: while the former concerned a social policy (survivor's pension), the latter involved the succession in a tenancy (hence it could be argued that its national strategic economic importance was negligible). Beyond this aspect, Karner v. Austria contains an element of innovation. In fact, in the judgment, the Court had conceded that 'protecting the traditional family' was quite a vague statement (Karner v. Austria 2003, para. 35). This has to be read in conjunction 
with the marginal importance that the Court had attributed to the issue of whether a homosexual relationship fell within the notion of either 'private life' and or 'family life' under Article 8 ECHR. For the Court, in fact, the alleged violation of Article 8 ECHR was only to be analysed under the profile of the 'right to respect for [one's] home' (Karner v. Austria, 2003: para. 31).

Therefore, on the one hand the Court had deemed proportional, in order to protect the traditional family, for a member state to discriminate against individuals in a same-sex relationship if a structural social or economic policy was at stake (such as in Mata Estevez v. Spain). On the other hand it had found it disproportionate for states to enact such discrimination when the issue concerned measures to prevent sudden homelessness after the death of one's partner. Such a distinction does not seem to follow any legal logic, as the discrimination would seem more significant if a portion of the population was experiencing an outright exclusion from a structural and economic policy without a robust justification for it.

The analysis of these two cases shows how the preservation of some economic privileges attached to marriage represents a prominent preoccupation for member states. Seen in this perspective, same-sex couples are requesting an improvement in their financial, as well as symbolic, position; but they also ask for legitimation as interlocutors of the state in order to become intelligible. In doing so, however, they implicitly re-instate the existing value of marriage and this may have a negative impact on those who do not wish to marry, as Warner (1999: 108) has maintained.

The work of the Commissioner takes into account the economic implications of the lack of legal recognition of same-sex couples. In the above-mentioned 2011 report, a dedicated section ('The Impact of Non-Recognition') lists all the challenges encountered, by same-sex couples, in terms of financial and socio-economic issues. Although the section serves as a brief compendium of the disadvantages experienced by same-sex couples, what it also achieves in practice, is the restatement of the principle that it would be good to extend marriage to a formerly excluded part of the populace. The authority of member states regarding which privileges are accessible through marriage are taken for granted. It would seem, therefore, that the work of the Commissioner is consistent with a 
homonormative pattern in the recognition of non-heterosexual kinship. Although the vulnerability, both material and symbolic, of LGBT persons is thoroughly acknowledged, the individuals who experiences these difficulties and hardships are, de-racialised, de-gendered and deprived of a specific connotation in terms of social class. The Commissioner's suggestion to member states to broaden the concept of marriage so as to include same-sex couples, therefore, does not aim at putting into question the distributive issues around marriage that exist in different member states. Rather, it points directly to the recognition of the symbolic value of this institution and the strategic role that it fulfills within member states.

\section{(Im)possible parents}

Often presented and framed as a corollary to the issue of marriage equality, the recognition of parental rights of lesbian, gay and bisexual persons has come to the forefront in political and legal, national and international, fora. There are, however, several problematic aspects, relating to how these requests are framed in relation to homonormativity. In this regard, Schroeder (2004: 104) gives an interesting account of her situation as a non-heterosexual parent:

I do know that the normalising factor (...) is noticeable in MY life. (...) I got more than my share of approval and attention. Hey, I was a lady with a baby. My relationships with people changed (...). Even being a lesbian didn't throw most people off, since I was now a legitimate woman, a MOTHER. At work in the store, in the street, the moment anyone found out I had a child, I was accepted, taken for granted as a 'normal' individual. That I am lesbian, queer, was secondary.

This passage summarises well the dilemma of respectability. Is the desire for parenthood an assimilationist move? The strand of the Court's jurisprudence ${ }^{13}$ regarding adoption by lesbian, gay 
and bisexual persons has been subject to an important acceleration in the last decade: from Fretté $v$. France in 2002 to $X$ and Others v. Austria in 2013. As a preliminary comment, it must be recalled that neither international instruments, nor the jurisprudence ${ }^{14}$ of the Court, recognise a 'right to adoption'. Applicants, in various cases, have tried to by-pass this problem by framing their applications in terms of an alleged violation of their right to respect for 'family life' under the terms of Article 8 ECHR, which led to a subsequent demand for a re-definition of the concept of 'family'. In Salgueiro da Silva Mouta v. Portugal (1999), the Court had already implicitly recognised that a lesbian, gay or bisexual parent could be as good as a heterosexual parent, while it had simultaneously established a dichotomy between good and bad examples of parenthood. In the following jurisprudence on custody and adoption, applicants have built precisely on this dichotomy in order to convince the Court. The applicants' effort to recreate and foster an idea(l) of respectability and irreprehensibility of LGB individuals as parents has been welcomed by an insistence, on the part of the Court, on a model of 'traditional family life' that has left little space for the negotiation of given meanings.

The concerted efforts of strategic litigation in this ambit, with the help of various human rights NGOs, demonstrate the crucial role of parenting in the process of gaining full equality. The result, overall, is that the centrality of the family is once again restated by activists, national authorities and international organisations (such as the $\mathrm{CoE}$ ) against the background of the pauperisation and marginalisation of some families or other forms of kinship (working class, with unemployed members and/or non-white, and/or monoparental) that do not match the spotless image of the modern family.

Over the last decade, the trajectory of the most recent jurisprudence of the Court on adoption has followed a contorted path. This is particularly evident if one compares the two cases concerning respectively adoption by a single person (Fretté v. France, 2002 and E.B. v. France, 2008) and the two cases concerning adoption by same-sex couples (Gas and Dubois v. France, 2012 and X and Others v. Austria, 2013) on the other. In Fretté v. France (2002) the applicant, a single man who 
had avowed (the Court's words) his homosexuality during the application process for adoption, ${ }^{15}$ alleged a violation of Article 8 ECHR in conjunction with Article 14 ECHR. Notwithstanding the excellent report by the social services as to his suitability as a parent, the French social services had also maintained that 'his emotional and sexual lifestyle' (Fretté v. France, 2002: para. 10) had proved to be a decisive factor in the final decision to strike down his application.

The Court, in analysing the necessity of ensuring, although only in theory, the 'best interests of the child', had relied on the existence of contrasting opinions within the scientific community (Fretté v. France, 2002: para. 42) in relation to the effects on children of adoption by gay or lesbian individuals. In judging the government's difference of treatment to be objective and reasonable, the Court dismissed the applicant's complaint. In 2008, however, in the case of E.B. v. France, the Court overturned Fretté v. France, by ascertaining the existence of an infringement of Article 8 in conjunction with Article 14 ECHR.

While Fretté v. France and E.B. v. France both concerned avowed homosexuals, the applicants' situations differed. E.B. had a partner who did not wish to be involved in the adoption process and in her case, the French social services had brought forward two main impediments to her suitability as parent: on the one hand the lack of a paternal figure, and on the other lack of commitment on the part of her partner. In E.B. v. France, however, the Court applied with more rigour the test of the 'legitimate aim' pursued by the government, with respect to Fretté v. France. Used by the government in order to justify the need for children to have both parents, the opinion of the 'scientific community' was dismissed by the Court as a legitimate ground to reject the applicant's request. The use of the experts' opinions, therefore, appears inconsistent in these two cases. Furthermore, within six years, the Court had clearly revised its evaluation of what it meant to protect the 'health and rights of children' (Fretté v. France, 2002, para. 38). This implied that in 2008 a single gay or lesbian person was legitimated as parent, by the means of a slippery concept, detected by the Court, of 'European consensus' on the issue. 
After E.B. v. France, the Court's jurisprudence on adoption by LGB individuals did not follow a linear trajectory. Although the Court had recognised that single LGB individuals were suitable to become parents, the same did not automatically apply to same-sex couples. Gas and Dubois v. France (2012) and $X$ and Others v. Austria (2013) concerned couples in which the non-biological parent wanted to gain full parental responsibility for their partner's child. They illustrate the inconsistency of the positions adopted by the Court on this topic, torn between the need to preserve the heteronormativity of parenthood and the necessity to regulate non-heterosexual parenthood within the boundaries of homonormative narratives.

In Gas and Dubois v. France the Court recognised the existence of a 'family life' between the applicants (Gas and Dubois, 2012: para. 37). At the same time, however, it deemed that the refusal to grant simple adoption to the non-biological parent was justified, under French law, because this was only available to married couples. The Court dismissed the applicants' allegation of a violation of Article 8 in conjunction with Article 14 ECHR. Furthermore, it did not consider the fact that the applicants could not get married in the first place, because of their sexual orientation, to be a discriminating factor.

While the 'best interests of the child' played a significant role, at the same time, the Court had placed a strong emphasis on the importance of the institution of marriage as one that conferred a particular status. The short circuit in the reasoning of the Court was reached, precisely, when the applicants affirmed that they were not seeking marriage (Gas and Dubois v. France, 2012: para. 42) and made a comparison between themselves and unmarried heterosexual couples. The implicit question became, therefore: why were the applicants not seeking marriage, although they considered themselves to be a family? Why were they advancing claims if they did not want to subscribe to social institutions? The Court proved to be unable to conceive of parenthood without the willingness to subscribe to familial institutions. It confirmed, therefore, that it was the member states' prerogative to decide which subjects, and under which conditions, could be more or less suitable for adoption. 
The Court, however, revised its own arguments, one year later, in X and Others v. Austria (2013), in which it practically overturned Gas and Dubois v. France. The case concerned a couple formed by two women. One of the applicants had a son to whom she had given birth without being married. The child's father had recognised his paternity and had regular contact with the child. However, the biological mother's female partner wanted to gain second-parent adoption. The Austrian Court had refused to grant it because the child already had two parents and also because the two women were not married (although marriage was not available for same-sex couples in Austria). In its assessment, the Court had found that the applicants formed a 'stable same-sex couple' ( $X$ and Others v. Austria, 2013: para. 26), and therefore considered that the notion of 'family life' was applicable. However, similarly to Gas and Dubois v. France, the applicants had neither expressed interest in entering a civil partnership (available in Austria but without effects upon 'second-parent' adoption), nor in marrying (not available in Austria for same-sex couples).

On the one hand, on the symbolic level, the refusal to seek legitimation by the means of adherence to institutions (such as partnership or marriage) may be said to signify, for the Court, a diminished level of commitment on the part of the applicants; and it could be said to weaken, in principle, the applicants' request to become parents in the eyes of the Court. On the other hand, in $X$ and Others $v$. Austria (2013), the Court ascertained a violation of Article 8 in conjunction with Article 14 ECHR, on the ground that the applicants had been discriminated against in comparison to non-married heterosexual couples. In affirming the violation the Court, nonetheless, gave an unprecedented emphasis to the necessity of recognising de facto families. This was a necessity that, in relation to same-sex couples, it had always been reluctant to concede. Such a change in the Court's position, in less than a year, represents a surprising evolution.

Elements of innovation, in $X$ and Others $v$. Austria, can also be noticed in relation to the crucial use of sociological analysis and legal analysis that the Court made in the judgment. In order to provide a socio-legal overview of the situation for LGB parents in the 47 member states, the Court had offered a detailed description of comparative law on the issue of 'second-parent' adoption but had 
also referred to the above-mentioned Commissioner's 2011 report. Such a reference demonstrates the attempt of the Court to furnish a more solid sociological basis on which to ground its reasoning beyond mere abstract legal speculation on the value of 'alternative families'. It furthermore shows how, within the Council of Europe, non-judicial institutions can also help frame the judgments of the Court, especially when there is a swift and dynamic evolution in European societies on some specific issues.

The interest of the Court in the Commissioner's work is particularly relevant, given the attention that the Commissioner himself was paying, at the time of the drafting of the report, to the then pending case of Gas and Dubois v. France (2012). In his office it was, in fact, possible to perceive the expectations of a possible evolution of the jurisprudence of the Court on the topic. These expectations were partly related to the recognition that the judgments of the Court could be used to support and give legitimacy to the work of the Commissioner, which could then be used to persuade national authorities to enact changes in national legislation. In the light of the Court's reliance, in $X$ and Others v. Austria, on the socio-legal work provided by the Commissioner, this aspect appears particularly striking. The Court needs the sociological data to back up its decision to broaden the concept of 'family life', while the Commissioner needs the Court's judgments in order to encourage member states to revise their human rights agenda. Such a mutual relationship surely represents an interesting development in the context of Court-Commissioner cooperation, and could form the object of future speculation.

This strand of jurisprudence of the Court also shows, however, how third parties are gaining importance in the litigation process. In $X$ and Others $v$. Austria, for instance, the intervening third parties were ten ${ }^{16}$ different human rights NGOs and other actors. This aspect is likely to become increasingly important, given the capability of different non-governmental actors to build networks and share information, as well as devising common European strategies in order to litigate both in Strasbourg and in national Courts. This, at the same time, represents another facet of homonormativity: the spasmodic necessity to seek regulation of one's status predominantly through 
the law. To this respect, it could be argued that, to some extent, strategic litigation may help to prioritise normative issues over material and structural problems connected with the lack of official recognition.

The over-normativisation of the status of 'parents', in the case of LGB persons, also overshadows the fact that adoption may not be a neutral process in the first place. As Smith (2009: 345) has argued, the insistence on the issue of adoption may hide the dynamics of economic deprivation that bring children to be placed in foster care or to be adopted. Smith offers the example of the United States and maintains that a considerable number of the children there placed in foster care, for instance, have not experienced abuses, but have been removed from their families because of the inability of their parents to provide for them. While not directly translatable into the European context, Smith's argument highlights the extent to which the 'battle' for parenthood may become almost an ideological one that overlooks the structural inequalities that lead to children being adopted in the first place. It could be suggested here that a reflexive stance on the issue of adoption would lessen the merely symbolic importance of this human rights campaign and promote critical reflections on the implications of parenthood in broader social and political terms.

The analysis carried out so far shows that judgments such as $X$ and Others $v$. Austria are likely to have a strong impact on national audiences and reverberations at the legislative level in various member states. The impact of the decisions of the Court, therefore, should not be underestimated in terms of developments across Europe. At the same time, however, the analysis of these judgments has also shown the existence of a strict normative framework within which kinship becomes possible in the first place. The domain of the law, remains the domain of legitimation and acquisition of intelligibility (Beger, 2000: 265).The crucial role of the law, and of judicial decisions more broadly, in the definition of what counts as a 'family' cannot be perceived as a neutral role. It has to be subjected to a critical analysis which highlights the complicity of the law with the various national and supra-national interests at stake in relation to the recognition of same-sex partnerships. 


\section{Conclusion: glimpsing the family from a distance}

This article has sought to analyse the jurisprudence of the European Court of Human Rights and the work done by the Commissioner for Human Rights of the Council of Europe on the recognition of same-sex couples, from a socio-legal and critical perspective. Far from taking such recognition for granted, it has tried to shed light on the principles governing the evolution of the jurisprudence, as well as the way in which the applicants have framed their requests in order to be successful in Strasbourg. It has also tried to read the jurisprudence of the Court and the work of the Commissioner under the lens of homonormativity (Duggan, 2003) and their entanglements with a European neoliberal political and economic agenda.

In the article it has been argued that the recognition of same-sex partnerships harbours a high degree of problematicity in relation to economic and financial strategies and also from a political point of view, as the strategies employed by the Commissioner to raise awareness on this topic have demonstrated. It has been suggested, in particular, that far from representing the key to the end of the subordination of lesbian, gay and bisexual persons in a heteronormative society, the recognition of same-sex partnerships may reinforce the very structures of exclusion that marginalise nonconforming individuals, creating a problematic concept of 'normality'. The question of marriage equality, in particular, seems to have become, in the current European discourses on the rights of LGB persons, the perfect embodiment of the neoliberal concept of 'autonomy' whereby the family becomes the primary structure of reference for individuals and a self-sufficient unit perfectly integrated in the globalised economic landscape from which the state shies away.

At the same time, far from endorsing a purely queer perspective on the issue of same-sex marriage, the position in this article has been one of cautious pragmatism. Echoing Gómez (2011: 27) it is possible to ask why marriage is the only point of access to the enjoyment of some benefits or privileges and why it overshadows the possibility of thinking about a fairer distribution of resources based on actual life conditions, rather than on formal prerequisites. The uncritical endorsement of 
1

2

3

4

5

6

7

8

9

10

marriage equality risks leaving the status quo unchallenged and unquestioned. While the option of marrying can be considered a positive achievement, exaggerating its symbolic importance for the obtainment of full equality is smoke and mirrors. It is with this awareness in mind, that it is possible to evaluate the future developments in the jurisprudence of the Court on this issue and also envisage a different configuration of what full equality for LGB persons would mean in practice.

This objective of actively reconfiguring the normative recognition of kinship (both heterosexual and non-heterosexual) can only be achieved if both activists and human rights institutions (the $\mathrm{CoE}$ ), as well as states, combine the discussion of the normative forms that kinship should take, with the question of how to progressively detach privileges from one's marital status. In fact, obtaining social and economic entitlements exclusively through marriage is far from being a marginal problem. On the contrary, the quest for marriage equality for lesbian, gay and bisexual persons requires a critical re-evaluation of the need to perpetuate the narrow framework of distribution of resources and public goods by means of marriage. 
1 At the moment two applications are pending before the Court: Chapin and Charpentier v. France, Application No. 40183/07, lodged 6 September 2007, and Ferguson and Others v. the United Kingdom, lodged 2 February 2011.

2 'Material consequences cover (...) different kinds of tax, health insurance, social security payments and pensions. (...) This also applies to other material consequences, such as regulations on joint property and debt, application of rules of alimony upon break-up, entitlement to compensation on wrongful death of partner and inheritance rights', (Schalk and Kopf v. Austria, 2010: para. 32).

3 Parental consequences include the opportunity to undergo medically assisted insemination or to foster or adopt children. (Schalk and Kopf v. Austria, 2010: para. 33).

4 'Other consequences include the use of the partner's surname, the impact on a foreign partner obtaining a residence permit and citizenship, refusal to testify, next-of-kin status for medical purposes, continued status as tenant upon death of the partner, and lawful donation of organs'.( Schalk and Kopf v. Austria, 2010: para. 34).

5 The role of the Commissioner for Human Rights of the Council of Europe has been established by the Committee of Ministers (CM) of the Council of Europe with the CM/Rec(1999)50 on the Council of Europe Commissioner for Human Rights, adopted on 7 May 1999. The Commissioner is appointed for a six-year mandate during which she/he carries out promotion and awareness-raising on various human rights issues, as well as cooperating with national governmental and non-governmental actors on specific themes in an impartial and independent way. The Commissioner also carries out fact-finding missions in member states, issues reports and recommendations and promotes the development of national human rights structures.

6 This is particularly true in Southern Europe, where the family plays the role of a substitute for welfare policies (Matsaganis, Ferrera Capucha and Moreno, 2003).

7 At the time of the complaint to the British Court the applicant had not given birth to her daughter yet, but she was pregnant.

8 Schalk and Kopf v. Austria is the first case in which the Court has stretched its conception of 'family life' so as to comprise same-sex couples. Prior to this case, in fact, all other applications that sought to challenge the standard interpretation of the wording of Article 8, had failed.

9 Under principles 2 and 6 of the United Nations Convention on the Rights of the Child.

10 See O'Donoghue v. the United Kingdom (2010).

11 At the time of the application, Spain had not introduced yet the possibility for same-sex couples to marry.

12 X. and Y. v. the United Kingdom, 1983 and S. v. the United Kingdom, 1986.

13 The previous landmark case, although unsuccessful for the applicants, had been Kerkhoven, Hinke and Hinke v. the Netherlands (1992). On a similar note, also the request of a transsexual man to be recognised as father failed before the Court in $X, Y$ and $Z$ v. the United Kingdom (1997).

14 See Di Lazzaro v. Italy (1997).

15 Articles 343 and 343-1 of the French Civil Code allow single persons to adopt.

16 Third-parties in $X$ and Others v. Austria (2013) included the International Federation for Human Rights (FIDH), the International Commission of Jurists (ICJ), the British Association for Adoption and Fostering (BAAF), the Network for European LGBT Families Association (NELFA), the European Commission for Sexual Orientation Law (ECSOL), the European Centre for Law and Justice (ECLJ), the Attorney General of Northern Ireland, Amnesty International (AI) and the Alliance Defending Freedom (ADF). 


\section{Bibliography}

\section{Cases Cited}

$X$ and $Y$ v. the United Kingdom, Application No. 9369/81, Commission Decision 3 May 1983.

S. v. the United Kingdom, Application No. 11716/85, Commission Decision 14 May 1986.

C. and L.M. v. the United Kingdom, Application No. 14753/89, Commission Decision 9 October 1989.

Kerkhoven, Hinke and Hinke v. the Netherlands, Application No. 15666/89, Commission Decision 19 May 1992.

$X, Y$ and $Z v$. the United Kingdom, Application No. 21830/93, Judgment 22 April 1997, European Court of Human Rights.

Di Lazzaro v. Italy, Application No. 31924/96, Commission Decision 10 July 1997.

Salgueiro da Silva Mouta v. Portugal, Application No. 33290/96, Judgment 21 December 1999, European Court of Human Rights. Mata Estevez v. Spain, Application No. 56156/00, Judgment 10 May 2001, European Court of Human Rights. 
Fretté v. France, Application No. 36151/97, Judgment 26 May 2002, European Court of Human Rights.

Karner v. Austria, Application No. 40016/98, Judgment 24 July 2003, European Court of Human Rights.

E.B. v. France, Application No. 43546/02, Judgment 22 January 2008, European Court of Human Rights.

Schalk and Kopf v. Austria, Application No. 30141/04, Judgment 24 June 2010, European Court of Human Rights.

O'Donoghue and Others v. the United Kingdom, Application No. 34848/07, Judgment 14 November 2010, European Court of Human Rights.

Gas and Dubois v. France, Application No. 25951/07, Judgment 15 March 2012, European Court of Human Rights.

X and Others v. Austria, Application No. 19010/07, Judgment 19 February 2013, European Court of Human Rights.

Chapin and Charpentier v. France, Application No. 40183/07, lodged 6 September 2007, pending.

Ferguson and Others v. the United Kingdom, lodged 2 February 2011. 


\title{
Recommendations and Resolutions
}

Committee of Ministers of the Council of Europe, CM/Rec(1999)50 on the Council of Europe Commissioner for Human Rights.

Committee of Ministers of the Council of Europe, Recommendation

CM/Rec(2010)5 of the Committee of Ministers to Member States on Measures to Combat Discrimination on Grounds of Sexual Orientation or Gender Identity. Parliamentary Assembly of the Council of Europe, Resolution 1728 (2010), Discrimination on the Basis of Sexual Orientation and Gender Identity.

\author{
References \\ Becker, GS (1973) A Theory of Marriage: Part I. Journal of Political Economy \\ $81(4): 813-46$. \\ Beger, NJ (2000) Queer Readings of Europe: Gender Identity, Sexual \\ Orientation and the (Im)potency of Rights Politics at the European Court of \\ Justice. Social \& Legal Studies 9(2): 249-270. \\ Black, DA, Sanders, SJ, and Taylor, LJ (2007) The Economics of Lesbian and \\ Gay Families. The Journal of Economic Perspectives 21(2): 53-70.
}


Brandzel, AL (2005) Queering Citizenship? Same-Sex Marriage and the State. GLQ: A Journal of Lesbian and Gay Studies 11(2): 171-204.

Butler, J (2002) Is Kinship Always Already Heterosexual? Differences: A Journal of Feminist Cultural Studies 13(1): 14-44.

Commissioner for Human Rights of the Council of Europe, (2011)Discrimination on Grounds of Sexual Orientation and Gender Identity, Council of Europe Publishing.

Duggan, L (2003) The Twilight of Equality: Neoliberalism, Cultural Politics, and the Attack on Democracy. Reprint. Beacon Press.

Eng, DL (2010) The Feeling of Kinship: Queer Liberalism and the Racialization of Intimacy. Duke University Press.

Fineman, MA (2009) The Sexual Family. In: Fineman, MA, Jackson, JE, and Romero, AP (2009) Feminist and Queer Legal Theory: Intimate Encounters, Uncomfortable Conversations. Farnham: Ashgate.

Franke, KM (2006) The Politics of Same-Sex Marriage Politics. Columbia Journal of Gender and Law 15(1): 236-48.

Johnson, P (2012) Homosexuality and the European Court of Human Rights. Routledge.

Kandaswamy, P (2008) State Austerity and the Racial Politics of Same-Sex 
Marriage in the US. Sexualities 11(6): 706-725.

Matsaganis, M, Ferrera M, Capucha L, Moreno L (2003) Mending Nets in the South: Anti-poverty Policies in Greece, Italy, Portugal and Spain. Social Policy \& Administration 37(6): 639-655.

McCluskey, MT (2009) How Queer Theory Makes Neoliberalism Sexy. In:

Fineman, MA, Jackson JE, and Romero AP (2009) Feminist and Queer Legal

Theory: Intimate Encounters, Uncomfortable Conversations. Farnham: Ashgate.

Motta, Carlos, Motta, Cristina, (ed.) (2011) We Who Feel Differently, Ctrl+z

Publishing.

Polikoff, ND (2005) For the Sake of All Children: Opponents and Supporters of Same-Sex Marriage Both Miss the Mark, New York City Law Review 8 : 573681.

Puar, JK (2007) Terrorist Assemblages: Homonationalism in Queer Times. Duke University Press.

Robson, R (2009), Compulsory Patrimony. In: Fineman, MA, Jackson JE, and Romero, AP (2009) Feminist and Queer Legal Theory: Intimate Encounters, Uncomfortable Conversations. Farnham: Ashgate.

Smith, AM (2009) From Paternafare to Marriage Promotion: Sexual Regulation and Welfare Reform. In: Fineman, MA, Jackson JE, and Romero AP (2009) 
Feminist and Queer Legal Theory: Intimate Encounters, Uncomfortable

Conversations. Farnham: Ashgate.

Spade, D (2011) Normal Life: Administrative Violence, Critical Trans Politics, and the Limits of Law. South End Press.

Sycamore, BM (2008) (ed). That's Revolting!: Queer Strategies for Resisting

Assimilation. Edited by Mattilda Bernstein Sycamore. Lesga. Soft Skull Press.

Taylor, Y (2009) Lesbian and Gay Parenting: Securing Social and Educational

Capital. New York: Palgrave Macmillan.

Waaldijk, K (1994) Standard Sequences in the Legal Recognition of

Homosexuality - Europe's Past, Present and Future. Australasian Gay and

Lesbian Law Journal 4 : 50.

Waaldijk, K (2000) Civil Developments: Patterns of Reform in the Legal

Position of Same-Sex Partners in Europe. Canadian Journal of Family Law 17:

62.

Waaldijk, K (2004) Others May Follow: The Introduction of Marriage, Quasi-

Marriage, and Semi-Marriage for Same-Sex Couples in European Countries.

New England Law Review 38: 569.

Warner, M (1999) The Trouble with Normal: Sex, Politics and the Ethics of

Queer Life. Cambridge: Harvard University Press. 
Weston, K (1997) Families We Choose: Lesbians, Gays, Kinship. New York: Columbia University Press.

Wintemute, R (1997) Sexual Orientation and Human Rights: The United States

Constitution, the European Convention, and the Canadian Charter. Oxford:

Clarendon Press.

Wintemute, R, Andenæs MT, and Centre of European Law (2001) Legal

Recognition of Same-sex Partnerships: a Study of National, European, and International Law. Hart Pub. 


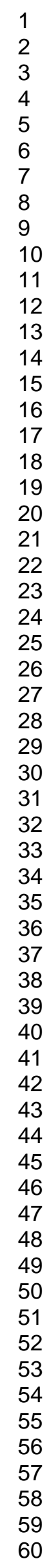

